\title{
EUROSON 2015
}

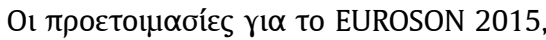

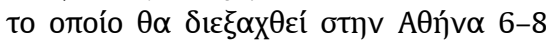

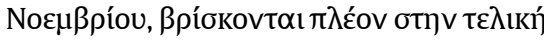

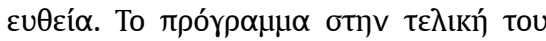

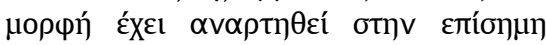

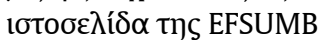

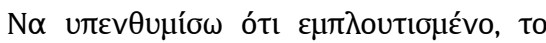

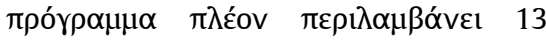

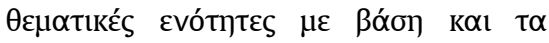

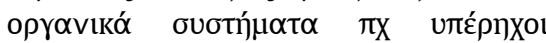

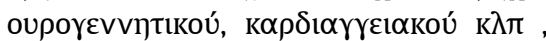

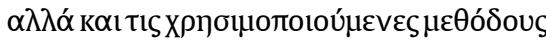

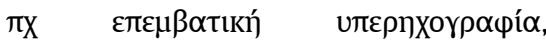

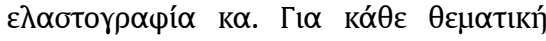

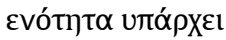

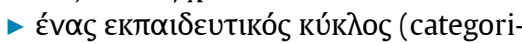

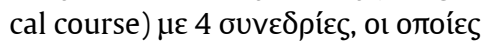

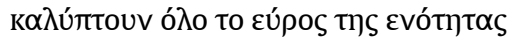
(A - Z lectures)

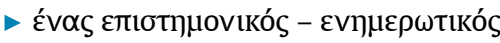

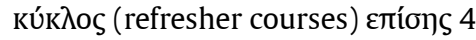

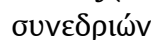

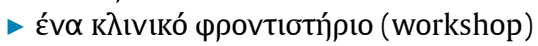

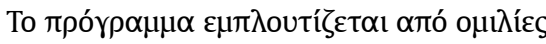

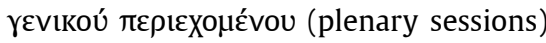

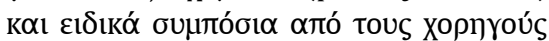

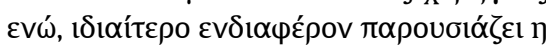

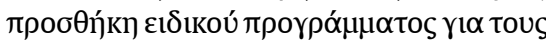

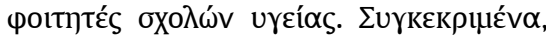

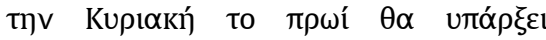

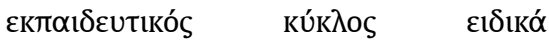

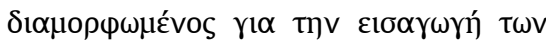

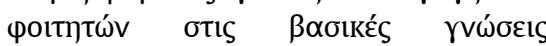

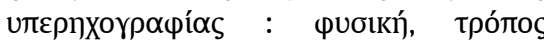

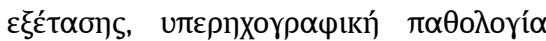

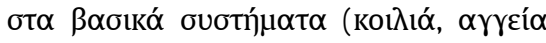
$\mathrm{k} \lambda \pi)$

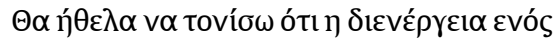

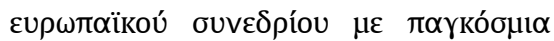

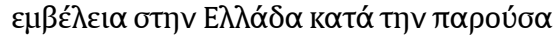

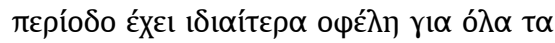

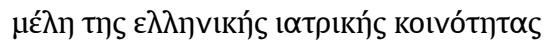

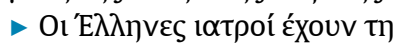

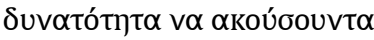
$\mu \varepsilon \gamma \alpha \lambda u ́ \tau \varepsilon \rho \alpha$ ovó $\mu \alpha \tau \alpha$ Tทऽ

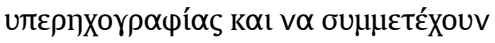

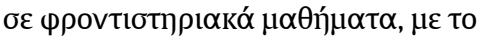

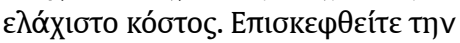

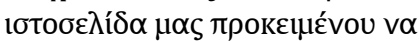

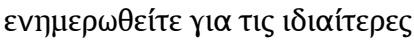

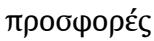

- Ev $\alpha \pi \varepsilon \tau u X \eta \mu \varepsilon ́ v o ~ \sigma u v \varepsilon ́ \delta \rho ı ~ \varepsilon i ́ v \alpha ı \eta$

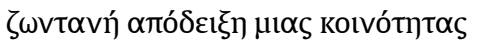

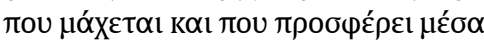

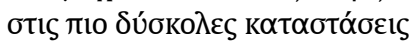

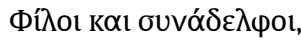

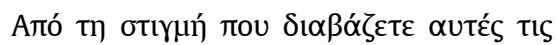

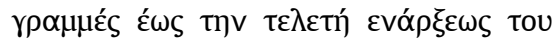

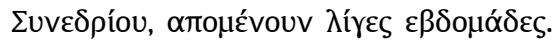

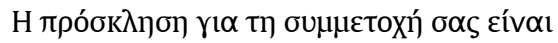

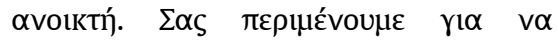

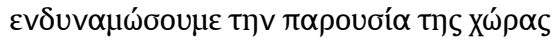

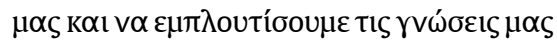

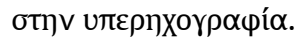

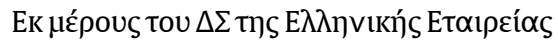

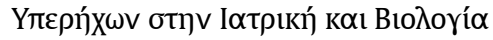

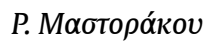

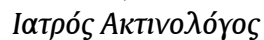

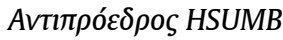

